PROFESI (Profesional Islam)

Media Publikasi Penelitian; 2017; Volume 15; No 1.

Website: ejournal.stikespku.ac.id

\title{
Hubungan Asupan Kalium dan Natrium dengan Dehidrasi pada Remaja di SMK Muhammadiyah 04 Boyolali
}

\author{
Lutfie Widya Sari Maslicha ${ }^{1 *}$, Tri Wibowo Anang ${ }^{2}$ \\ ${ }^{1 *}$ Program Studi Ilmu Gizi Fakultas Ilmu Kesehatan Universitas Muhammadiyah Surakarta \\ ${ }^{2)}$ Departemen Ilmu Gizi Universitas Muhammadiyah Surakarta \\ *Email: lutfiewidyasm@yahoo.com
}

\begin{abstract}
Kata Kunci
Asupan kalium,

Asupan natrium,

Remaja dan

Dehidrasi
\end{abstract}

\begin{abstract}
Abstrak
Dehidrasi merupakan kekurangan cairan diakibatkan cairan yang masuk lebih sedikit dibandingkan cairan yang keluar. Banyak faktor yang mempengaruhi terjadinya dehidrasi diantaranya gangguan keseimbangan cairan elektrolit (kalium dan natrium), yang fungsinya menjaga keseimbangan cairan dan asam basa tubuh. Penelitian ini bertujuan untuk mengetahui hubungan asupan kalium dan asupan natrium dengan kejadian dehidrasi pada remaja. Penelitian menggunakan metode cross sectional dengan melibatkan 64 subjek. Pengambilan sampel menggunakan teknik Simple Random Sampling. Penelitian dilakukan di SMK Muhammadiyah 04 Boyolali. Data jenis kelamin dan umur di dapat dari formulir identitas responden, data asupan kalium dan asupan natrium terdiri jumlah porsi dan frekuensi konsumsi yang didapat dengan menggunakan semi kuantitatif Food Frequency Questionnaire (FFQ) dan kejadian dehidrasi didapatkan dengan metode Pemeriksaan Urin Sendiri (PURI) kemudian dibandingkan dengan grafik PURI. Analisis hubungan asupan kalium dengan kejadian dehidrasi menggunakan metode Pearson Product Moment, sedangkan hubungan asupan natrium dengan kejadian dehidrasi menggunakan metode Rank Spearman. Hasil data jenis kelamin didapat laki-laki 70,3\% dan perempuan 29,7\%, umur sebagian besar 16 tahun sebesar 42,2\%, asupan kalium kurang 96,9 $\%$ dan lebih 3,1\%, asupan natrium kurang 79,7\% dan lebih 20,3\%, kejadian dehidrasi berat 50,0\%, dehidrasi ringan 45,3\%, hidrasi baik 4.7\%. Hasil uji Pearson Product Moment tidak ada hubungan asupan kalium dengan kejadian dehidrasi, dengan nilai $p=0,494$; asupan natrium dengan uji Rank Spearman tidak ada hubungan dengan kejadian dehidrasi, dengan nilai $p=0,331$. Asupan kalium dan asupan natrium dapat mempengaruhi status dehidrasi walaupun secara empiris antara asupan kalium dan asupan natrium dengan kejadian dehidrasi tidak ada hubungan.
\end{abstract}

\section{The Correlation Between Potassium and Sodium Intake with the Genesis Dehydration on Adolecents at SMK Muhammadiyah 04 Boyolali}

\section{Keywords}

Potassium Intake, Sodium Intake, Adolescents

\section{Abstract}

Dehydration is a condition of lack of liquid caused by liquid intake less than liquid outcome. A lot of factors affect the dehydration including electrolytes liquid balance (potassium and sodium), which its function is maintain liquid and acid base belance of the body. The research aims to determine the correlation between potassium and sodium intake with dehydration in adolescents. The research used cross sectional method with 64 subjects. The sample collection technique using simple random sampling. The research was done in SMK Muhammadiyah 04 Boyolali. Data on sex and age were collected through respondents identity form, data intake of potassium and sodium including portions and frequency were gainedly Semi Quantitative Food Frequency Questionnaire (FFQ) and 
dehydration status was collected through urine self examination urine (PURI) then compared with the PURI chart. The analysis of correlations between the intake of potassium and dehydration using Pearson Product Moment, while correlations between sodium intake and dehydration using Rank Spearman. The results showed that $70.3 \%$ respondents were men and $29,7 \%$ were women, majority of age was 16 years 42,2\%. Respondents categorizes have low potassium intake were $96,9 \%$, hight potassium intake were $3,1 \%$, low sodium intake were $79,7 \%$ and high sodium intake were $20,3 \%$. The incidence of heavy dehydration was $50.0 \%$, light dehydration was $45,3 \%$ and good hydration was $4,7 \%$. The results of the Pearson Product Moment indicates that there was no correlation between potassium intake and dehydration, with the $p=0,494$, the correlation between intake sodium incident of dehydration analyted with Rank Spearman, with the $p=0,331$. Potassium and sodium intake can affect dehydration status although there was no correlation between potassium and sodium intake with incidence of dehydration empirically.

\section{PENDAHULUAN}

Perubahan yang terjadi pada remaja menimbulkan permasalahan dan perilaku, perubahan perilaku pada remaja salah satunya perubahan perilaku makan baik mengarah ke perilaku makan yang sehat ataupun mengarah kepada perilaku makan yang tidak sehat (Dilla, 2014).

Saat beraktifitas kebutuhan tubuh akan meningkat, salah satunya kebutuhan mineral pada remaja. Kebutuhan mineral untuk usia remaja sangat berbeda dengan kebutuhan pada saat anakanak. Mineral berfungsi untuk membuat kerja tubuh lebih baik, contoh mineral yaitu mineral kalium dan mineral natrium. Kalium ditemukan di hampir seluruh tubuh dalam bentuk elektrolit dan banyak terdapat pada saluran pencernaan. Sebagian besar kalium tersebut berada di dalam sel, sebagian lagi terdapat di luar sel. Mineral ini akan berpindah secara teratur dari dan keluar sel, tergantung kebutuhan tubuh. Di dalam tubuh, kalium biasanya bekerja sama dengan natrium dalam mengatur keseimbangan muatan elektrolit cairan tubuh. Elektrolit merupakan substansi yang menghantarkan arus listrik, yang berdisosiasi menjadi ion positif dan ion negatif diukur dengan kapasitasnya untuk saling berikatan (Horne, 2001). Ada dua tipe elektrolit dalam tubuh yaitu anion dan kation, anion merupakan elektrolit yang bermuatan negatif dan kation merupakan elektrolit yang bermuatan positif. Keseimbangan cairan elektrolit dijaga dengan menyesuaikan jumlah asupan kalium dari makanan dan jumlah kalium yang dibuang. Elektrolit sangat penting dalam membantu sel untuk menghasilkan energi dan menjaga stabilitas dinding sel, sehingga dapat berfungsi sebagaimana mestinya.

Kalium merupakan elektrolit yang terdapat di dalam tubuh manusia maupun hewan yang dibutuhkan untuk menjaga keseimbangan asam dan basa (Nasution dan Darwin, 1998) serta berperan dalam transmisi saraf dan kontraksi otot (Listiyaningsih dkk, 2014). Hal yang mempengaruhi jumlah kalium adalah umur dan jenis kelamin. Jumlah kalium dalam tubuh merupakan cermin keseimbangan kalium yang masuk dan keluar. Pemasukan kalium melalui saluran cerna tergantung dari jumlah dan jenis makanan (Yaswir, 2012).

Fungsi kalium menurut Kartasapoetra (2005) adalah sebagai berikut: (1) Merupakan unsur anorganik yang penting di dalam cairan intraseluler. (2) Penting dalam transmisi implusimplus saraf. (3) Penting untuk kontraksi otot. (4) Penting untuk pertumbuhan. Sumber utama kalium adalah makanan mentah atau segar, terutama buah, sayuran, dan kacang-kacangan (Almatsier, 2009).

Natrium adalah ion utama dalam cairan ekstraseluler tubuh yang mempunyai fungsi menjaga keseimbangan cairan dan asam basa tubuh serta berperan dalam transmisi syaraf dan kontraksi otot. Jumlah natrium dalam tubuh adalah gambaran keseimbangan natrium yang masuk dengan natrium yang di keluarkan. Pemasukan natrium yang berasal dari epitel mukosa saluran cerna dengan proses difusi dan pengeluarannya melalui ginjal atau saluran cerna 
PROFESI (Profesional Islam)

Media Publikasi Penelitian; 2017; Volume 15; No 1.

Website: ejournal.stikespku.ac.id

atau keringat di kulit (Darwis, 2008 dan scott, 2006). Natrium akan berfungsi untuk menjaga keseimbangan cairan dalam tubuh, menjaga aktivitas saraf, kontraksi otot dan juga berperan dalam proses absorpsi glukosa (Irawan, 2007).

Menurut Almatsier (2005) sumber natrium yang ada di dalam makananan antara lain: (1) Makanan yang diawetkan dengan garam dapur: Ikan asin, terasi, ebi, udang kering, telur asin, telur pindang, buah kaleng, asinan. (2) Makanan laut. (3) Makanan yang mengandung natrium/ pengawet: Roti, biskuit, sosis, cornet, kecap, petis, tauco. (4) Makanan ringan. (5) Makanan siap saji. (6) garam.

Kalium dan natrium merupakan cairan elektrolit, dan merupakan salah satu kompenen terbesar di dalam tubuh untuk kelangsungan proses metabolisme di dalam tubuh, metabolisme akan berjalan dengan baik apabila cairan di dalam tubuh terpenuhi. Ketidakseimbangan cairan di dalam tubuh dapat menyebabkan dehidrasi, ada beberapa faktor lain yang dapat menyebabkan dehidrasi antara lain: Suhu, aktifitas fisik dan diare. Dehidrasi adalah kekurangan cairan yang diakibatkan cairan yang masuk lebih sedikit dibandingkan dengan cairan yang keluar (Almatsier, 2009). Menurut Asian Food Information Centre (2000) dehidrasi dibagi menjadi tiga kelompok, yaitu dehidrasi ringan, dehidrasi sedang dan dehidrasi berat. Penyebab tubuh mengalami dehidrasi adalah aktifitas fisik, suhu, gangguan keseimbanga cairan elektrolit, diare dan kurangnya asupan air atau cairan (Narendra, 2007).

The Indonesian Hydration Regional Study (THIRST) tahun 2010 dilakukan di beberapa kota di Indonesia Jakarta menempati angka dehidrasi kedua setelah Makassar sebesar 53,1 \%, pada kelompok remaja usia 15 tahun sampai 18 tahun sebesar 49,5\%. Penelitian di Indonesia yang dilakukan oleh Hardinsyah, dkk (2008) dan bekerja sama dengan Danone Aqua Indonesia yang dilakukan di dataran tinggi (Lembang) dan dataran rendah (Jakarta Utara) menunjukkan bahwa presentasi dehidrasi ringan pada kelompok remaja lebih tinggi di dataran rendah di bandingkan di dataran tinggi, yaitu pada kelompok remaja yang mengalami dehidrasi ringan di dataran tinggi sebesar $24,75 \%$ dan di dataran rendah sebesar $41,70 \%$.
Berdasarkan hasil studi pendahuluan yang dilakukan pada bulan Juni 2016 terhadap 32 siswa siswi kelas satu di SMK Muhammadiyah 04 Boyolali didapat bahwa 59,37\% mengalami dehidrasi. Penelitian ini dilakukan dengan metode Pengujian Urin Sendiri (PURI) metode ini merupakan cara mengetahui kadar hidrasi dengan cara melihat skala warna urine dari kartu PURI sebagai indikator warnannya (PDGMI, 2012). Penilitian dilakukan di sekolah tersebut karena jumlah siswa dan siswi yang mengalami dehidrasi cukup banyak sebesar 59,37\%, lokasi sekolah yang mudah untuk mengakses makanan, aktivitas fisik dengan kegiatan ektrakurikuler di sekolah yang memadai dan kelengkapan fasilitas sekolah sehingga dapat mendukung penelitian ini.

Berdasarkan hal tersebut, maka peneliti ingin mengetahui hubungan asupan kalium dan asupan natrium dengan kejadian dehidrasi di SMK Muhammadiyah 04 Boyolali.

\section{METODE PENELITIAN}

Jenis penelitian ini merupakan penelitian deskriptif dan bersifat observasional dengan pendekatan cross sectional, pengambilan data dilakukan pada bulan september 2016, di SMK Muhammadiyah 04 Boyolali.

\subsection{Responden}

Sebanyak 64 responden siswa-siswi SMK Muhammadiyah 04 Boyolali yang terlibat dalam penelitian ini yang diambil dengan teknik Proporsional Random Sampling, yaitu dengan cara pengambilan sampel secara proporsi dilakukan secara simple, dengan metode pengambilan sampel secara acak yang mana masing-masing populasi mempunyai peluang yang sama besar untuk dipilih menjadi sampel (Murti, 2006).

\subsection{Asupan Kalium}

Pengumpulan data asupan kalium dalam penelitian ini didapatkan dengan cara wawancara langsung dengan responden menggunakan semi quantitative food frequency questionnaire selama satu bulan terakhir yang terdiri dari jumlah porsi yang dikonsumsi, frekuensi asupan kalium yang dikonsumsi. Jumlah asupan kalium yang dikonsumsi diukur dengan menggunakan Nutrisurvey 
dalam satuan miligram $(\mathrm{mg})$, dengan skala data rasio.

\subsection{Asupan Natrium}

Pengumpulan data asupan natrium dalam penelitian ini didapatkan dengan cara wawancara langsung dengan responden menggunakan semi quantitative food frequency questionnaire selama satu bulan terakhir yang terdiri dari jumlah porsi yang dikonsumsi, frekuensi asupan natrium yang dikonsumsi. Jumlah asupan natrium yang dikonsumsi diukur dengan menggunakan Nutrisurvey dalam satuan miligram (mg), dengan skala data rasio.

\subsection{Status Dehidrasi}

Pengumpulan data status dehidrasi dalam penelitian ini didapat dengan cara Pemeriksaan Urin Sendiri (PURI), dengan menampung urin dalam wadah transparan atau bening kemudian bandingkan dengan grafik PURI, membandingkan warna urin dengan grafik dengan pencahayaan yang terang dibawah sinar matahari atau dibawah lampu neon berwarna putih. Grafik PURI Yang menunjukkan nomor pada grafik apabila 1-3 hidrasi dengan baik, 4-6 dehidrasi ringan dan 7-8 dehidrasi berat, dengan skala data Ordinal.

\subsection{Analisis Data}

Analisis data disajikan dalam tabel distribusi dan variabel yang diteliti meliputi asupan kalium, kategori asupan kalium, asupan natrium, kategori asupan natrium, variabel tingkat dehidrasi dan status dehidrasi. Untuk mendeskripsikan data yang diperoleh berupa data distribusi dan persentase. Uji statistik yang digunakan dalam penelitian ini uji kenormalan One Sampel Kolmogorof Smirnov. Uji kenormalan data untuk mengetahui normalitas data asupan kalium dan asupan natrium. Asupan kalium setelah dilakukan uji kenormalan data didapat data normal sehingga dilanjutkan dengan uji Pearson Product Moment, asupan natrium setelah dilakukan uji kenormalan data didapat data tidak normal sehingga dilanjutkan dengan uji Rank Spearman.

\section{HASIL DAN PEMBAHASAN \\ 4.1 Gambaran Umum}

SMK Muhammadiyah 04 Boyolali berdiri pada tahun 1997, yang berlokasi di jalan lembayung no 4 Boyolali. Jumlah guru atau tenaga mengajar dan karyawan sebanyak 60 guru dan 25 karyawa. Sedangkan jumlah siswa kelas X, XI dan XII sebanyak 1332 siswa, yang dibagi kelas X sebanyak 576 siswa, jumlah siswa kelas XI sebanyak 396 siswa, dan jumlah siswa kelas XII sebanyak 360 siswa.

SMK Muhammadiyah 04 Boyolali memiliki kompetensi keahlian diantaranya teknik kendaran ringan (Mobil), teknik sepeda motor, teknik pemeliharaan mekanik industri, rekayasa perangkat lunak (RPL), tata boga,farmasi dan multimedia.

Sarana prasarana di SMK Muhammadiyah 04 Boyolali sangat memadai dan terdapat beberapa fasilitas untuk menunjang kegiatan proses belajar mengajar sekolah yang terdiri dari ruang kelas, ruang guru, ruang kepala sekolah, ruang tata usaha $(\mathrm{TU})$, ruang $\mathrm{BP} / \mathrm{BK}$, ruang laboratorium komputer, bengkel industri, bengkel otomotif, laboratorium Tata Boga, laboratorium bahasa, ruang usaha kesehatan sekolah (UKS), ruang OSIS, ruang koperasi, toilet, masjid, ruang gudang, ruang penjaga sekolah, pos satpam, dan tempat parkir.

Siswa-siswi mudah mengakses makanan dan minuman dikantin sekolah, supermarket disekitar sekolah dan penjual makanan keliling yang banyak berjualan di luar sekolah.

\subsection{Gambaran Asupan Kalium dan Natrium}

Gambaran asupan kalium dan natrium siswa dan siswi di SMK Muhammadiyah 04 Boyolali, berdasarkan hasil penelitian yang dilakukan dengan metode Food Frequensi Questionaire (FFQ), dapat dilihat pada Tabel 1 dan Tabel 2.

Tabel 1. Rata-rata Asupan Kalium dalam Satu Bulan

\begin{tabular}{lc}
\hline \multicolumn{1}{c}{ Sumber Kalium } & Persentase $(\%)$ \\
\hline Jeruk manis & 80,5 \\
Teh & 76,3 \\
Kacang tanah & 69,4 \\
Tempe & 66,6 \\
Tahu & 66,6 \\
Brokoli & 63,8 \\
Kentang & 59,7 \\
Pisang Ambon & 55,5 \\
Kelapa & 55,5 \\
Kacang hijau & 54,1 \\
\hline
\end{tabular}


Berdasarkan hasil Tabel 1. asupan kalium sebagian besar subjek mengkonsumsi jeruk manis tiap bulannya sebanyak $80,5 \%$ degan kandungan kalium $137 \mathrm{mg}$ dan asupan kalium yang paling sedikit dikonsumsi adalah kacang hijau sebanyak 54,1\% mengandung kalium 1132 mg (Almatsier, 2006

Tabel 2. Rata-rata Asupan Natrium dalam Satu Bulan

\begin{tabular}{lc}
\hline Sumber Kalium & Persentase (\%) \\
\hline Sosis & $84,7 \%$ \\
Saos Sambal & $79,1 \%$ \\
Kecap & $76,3 \%$ \\
Biskuit & $70,8 \%$ \\
Telur ayam & $69,4 \%$ \\
Telur Bebek & $69,4 \%$ \\
Susu Kental Manis & $69,4 \%$ \\
Roti Putih & $68,0 \%$ \\
Sarden & $68,0 \%$ \\
Keju & $66,6 \%$ \\
\hline
\end{tabular}

Berdasarkan Tabel 2. asupan natrium sebagian besar subjek mengkonsumsi Sosis tiap bulannya sebanyak $84,7 \%$ degan kandungan natrium $1000 \mathrm{mg}$, dan asupan natrium yang paling sedikit dikonsumsi subjek adalah keju $66,6 \%$ mengadung natrium $1250 \mathrm{mg}$ (Almatsier, 2006).

\subsection{Karakteristik Sampel Penelitian}

Sampel yang digunakan dalam penelitian ini adalah siswa-siswi yang berada di SMK Muhammadiyah 04 Boyolali yang sesuai dengan kriteria inklusi dan eksklusi yang telah ditentukan oleh peneliti. Sesuai dengan hasil penelitian diperoleh data subjek penelitian meliputi distribusi berdasarkan jenis kelamin dan umur Tabel 3.

Tabel 3. Karakteristik Responden $(n=64)$

\begin{tabular}{lcc}
\hline \multicolumn{1}{c}{ Karakteristik } & $\mathrm{N}$ & $\begin{array}{c}\text { Persentase } \\
(\%)\end{array}$ \\
\hline $\begin{array}{l}\text { Jenis Kelamin } \\
\text { Laki-laki }\end{array}$ & 45 & 70,3 \\
Perempuan & 19 & 29,7 \\
\hline Umur & & \\
14 tahun & 1 & 1,6 \\
15 tahun & 25 & 39,7 \\
16 tahun & 37 & 42,2 \\
17 tahun & 11 & 17,2 \\
\hline
\end{tabular}

Berdasarkan Tabel 3. pada penelitian ini sebagian besar subjek berjenis kelamin laki-laki sebanyak 45 subjek (70,3\%), dan subjek perempuan sebanyak 19 (29,7\%). Hal ini sesuai dengan kondisi jumlah remaja di SMK Muhammadiyah 04 Boyolali yang sebagian besar berjenis kelamin laki-laki. Subjek pada penelitian ini sebagian besar serumur 16 tahun 27 subjek $(42,2 \%)$ dan ada satu subjek yang berumur 14 tahun $(1,6 \%)$.

\subsection{Distribusi Subjek berdasarkan Asupan Kalium}

Asupan kalium diperoleh dari rata-rata jumlah kalium perhari yang berasal dari makanan yang dikonsumsi oleh subjek. Asupan kalium didapat dari hasil wawancara menggunakan form FFQ yang berisi jenis, porsi dan frekuensi mengkonsumsi makanan selama satu bulan. Data asupan kalium dan kategori asupan kalium dapat dilhat pada Tabel 4 dan Tabel 5.

Tabel 4. Distribusi berdasarkan Asupan Kalium

\begin{tabular}{lllll}
\hline Variabel & Mean & SD & Min & Max \\
\hline Asupan & 1750,37 & 1124,2 & 210,2 & 5840,0 \\
Kalium & & 2 & & \\
\hline
\end{tabular}

Tabel 5. Distribusi Berdasarkan Kategori Asupan Kalium

\begin{tabular}{ccc}
\hline Asupan Kalium & Frekuensi & Persentase (\%) \\
\hline Lebih & 2 & 3,1 \\
Kurang & 62 & 96,9 \\
\hline
\end{tabular}

Berdasarkan Tabel 4. menunjukkan mean atau rata-rata asupan kalium adalah $1750,37 \mathrm{mg}$. Hal ini dapat diartikan bahwa rata-rata subjek memiliki asupan kalium yang kurang. Nilai minimal asupan kalium adalah 210,2, nilai tersebut dapat diartikan bahwa asupan kalium kurang. Menurut AKG (2013) Kategori asupan kalium kurang untuk remaja laki-laki usia 13 tahun hingga 18 tahun yaitu $<4700 \mathrm{mg}$, sedangkan asupan kalium kurang untuk remaja perempuan usia 13 tahun sampai 15 tahun $<4500 \mathrm{mg}$, untuk remaja perempuan usia 16 tahun-18 tahun $<4700 \mathrm{mg}$. Nilai maksiimum asupan kalium 5840,0 mg. Kategori nilai tersebut dapat diartikan bahwa asupan kalium subjek tinggi, karena kategori asupan kalium $>4700 \mathrm{mg}$. Nilai standart deviasi adalah 1124,37.

Berdasarkan data Tabel 5. menunjukkan bahwa presentase asupan kalium sebagian besar kurang dibandingkan asupan kalium yang lebih, 
asupan kalium kurang yaitu $996,6 \%$ dengan frekuensi 62 subjek, sedangkan asupan kalium yang lebih sebesar 3,1\% dengan frekuensi 2 subjek.

Dari hasil wawancara ternyata subjek jarang mengkonsumsi buah-buahan terutama makanan yang mengandung kalium, kalium sangat mudah didapatkan pada bahan makanan yang sering dikonsumsi sehari-hari seperti pisang, namun kebiasaaan makan yang kurang baik merupakan faktor utama terjadinya asupan kalium yang kurang.

Kekurangan kalium disebut juga dengan hipokalemia. Penyebab hipokalemia yaitu pemberian diet rendah kalori untuk menurunkan berat badan. Pengeluaran kalium yang berlebihan tejadi memalui saluran cerna seperti muntahmuntah (Proverawati, 2011). Kelibihan kalium didalam tubuh disebut dengan hiperkalemia, hiperkalemia disebabkan karena keluarnya kalium dari intrasel ke ekstrasel yang dapat terjadi pada keadaan asidosis metabolik bukan asidosis organik (ketoasidosis, asidosis laktat), defisit insulin, katabolisme jaringan menigkat (Nirmala, 2010).

\subsection{Distribusi Subjek berdasarkan Asupan Natrium}

Asupan natrium diperoleh dari rata-rata jumlah natrium perhari yang berasal dari makanan yang dikonsumsi oleh subjek. Asupan natrium didapat dari hasil wawancara menggunakan form FFQ yang berisi jenis, porsi dan frekuensi mengkonsumsi makanan selama satu bulan. Data subjek berdasarkan asupan natrium dan kategori asupan natrium dapat dilhat pada Tabel 6 dan Tabel 7.

Tabel 6. Distribusi Berdasarkan Asupan Natrium

\begin{tabular}{lllll}
\hline Variabel & Mean & SD & Min & Max \\
\hline $\begin{array}{l}\text { Asupan } \\
\text { Natrium }\end{array}$ & 991,49 & 990,89 & 50,0 & 6631,6 \\
\hline
\end{tabular}

Tabel 7. Distribusi Berdasarkan Kategori Asupan Natrium

\begin{tabular}{ccc}
\hline Asupan Natrium & Frekuensi & Persentase (\%) \\
\hline Lebih & 13 & 20,3 \\
Kurang & 51 & 79,7 \\
\hline
\end{tabular}

Berdasarkan Tabel 6. menunjukkan mean atau rata-rata asupan natrium adalah $991,49 \mathrm{mg}$. Hal ini dapat diartikan bahwa rata-rata subjek memiliki asupan natrium yang kurang. Nilai minimal asupan natrium adalah 50,0, nilai tersebut dapat diartikan bahwa asupan natrium kurang. Menurut AKG (2013) kategori asupan natrium kurang untuk remaja laki-laki usia 13 tahun hingga 18 tahun yaitu $<1500 \mathrm{mg}$, sedangkan asupan natrium kurang untuk remaja perempuan usia 13 tahun sampai 18 tahun $<1500$ mg. Nilai maksimum asupan natrium $6631,6 \mathrm{mg}$. Kategori nilai tersebut dapat diartikan bahwa asupan natrium subjek tinggi, karena kategori asupan natrium $>1500 \mathrm{mg}$. Nilai standart deviasi adalah 990,89 .

Dari data Tabel 7. menunjukkan bahwa presentase asupan natrium sebagian besar kurang dibandingkan asupan natrium yang lebih, asupan natrium kurang yaitu 79,7\% dengan frekuensi 51 subjek, sedangkan asupan natrium yang tinggi sebesar 20,3\% dengan frekuensi 13 subjek.

Konsumsi natrium yang kurang menyebabkan volume darah menurun yang membuat tekanan darah menurun, denyut jantung meningkat, pusing, terkadang kram otot, lemas, lelah, penurunan nafsu makan, daya ingat menurun (Dwi, 2007). Peningkatan natrium plasma karena kehilangan air dan larutan ekstrasel (dehidrasi hiperosmotik) atau karena natrium dalam cairan ekstrasel seperti pada overhidrasi osmotik atau retensi air oleh ginjal dapat menyebabkan peningkatan osmolaritas dan konsentrasi natrium klorida dalam cairan ektrasel (Ridwan 2009).

\subsection{Distribusi Subjek berdasarkan Dehidrasi}

Distribusi dehidrasi diperoleh dari hasil ratarata pengujian urin sendiri menggunakan grafik puri oleh subjek. Tingkat dehidrasi dan kategori dehidrasi dapat dilihat pada Tabel 8 dan Tabel 9.

Tabel 8. Distribusi Tingkat Dehidrasi

\begin{tabular}{ccc}
\hline Status Dehidrasi & Frekuensi & Persentase (\%) \\
\hline 3 & 4 & 6,3 \\
4 & 12 & 18,8 \\
5 & 16 & 25,0 \\
6 & 8 & 12,5 \\
7 & 22 & 34,4 \\
8 & 2 & 3,1 \\
\hline
\end{tabular}


Tabel 9. Distribusi Kategori Dehidrasi

\begin{tabular}{ccc}
\hline Dehidrasi & Frekuensi & Persentase (\%) \\
\hline Hidrasi baik & 3 & 4,7 \\
Dehidrasi ringan & 29 & 45,3 \\
Dehidrasi berat & 32 & 50,0 \\
\hline
\end{tabular}

Berdasarkan Tabel 8. menunjukkan bahwa persentase dehidrasi dengan pemeriksaan PURI (Pemeriksaan Urin Sendiri) tertinggi menunjukkan diangka 7.00 yang menunjukkan dehidrasi berat dengan frekuensi sebanyak 22 dan persentase $(34,4 \%)$. Dehidrasi berat terjadi karena aktivitas fisik yang tinggi yang menunjukkan subjek banyak melakukan kegiatan ektrakurikuler, hal ini menyebabkan meningkatnya metabolisme dalam tubuh dan meningkatnya pengeluaran cairan, suhu lingkungan yang tinggi dapat menyebabkan proses pengeluaran cairan melalui keringat cukup banyak, dan kekurangan cairan eksternal atau dehidrasi dapat terjadi karena penurunan asupan cairan dan kelebihan pengeluaran cairan, gangguan cairan elektrolit dan diare (Arlita, 2014).

Dari data Tabel 9. diklasifikasikan kategori dehidrasi menunjukkan dehidrasi berat banyak dialami subjek di SMK Muhammadiyah 04 Boyolali dengan frekuensi 32 dan presentase $(50,0 \%)$, dan dehidrasi ringan dengan frekuensi 29 subjek dan presentase (45,3\%), sedangkan subjek yang mengalami hidrasi baik dengan frekuensi 3 dan presentase $(4,7 \%)$.

\subsection{Hubungan Asupan Kalium dengan Dehi- drasi}

Tabel 10. Analisis asupan kalium berdasarkan dehidrasi

\begin{tabular}{lccccc}
\hline Variabel & Mean & SD & Min & Max & p \\
\hline $\begin{array}{l}\text { Asupan } \\
\text { Kalium }\end{array}$ & 1750,37 & 1124,22 & 210,2 & 5840,0 & $0,494^{*}$ \\
Dehidrasi & 5,59 & 1,37 & 3,00 & 8,00 & \\
\hline Pearson Product Momen
\end{tabular}

Berdasarkan Tabel 10. menunjukkan bahwa rata-rata asupan kalium adalah 1750,37 $\mathrm{mg}$ yang menunjukkan dalam kategori kurang, sedangkan rata-rata dehidrasi 5,59 hal ini menunjukkan dalam kategori dehidrasi ringan. Hasil uji statistik dengan menggunakan metode Pearson Product Moment didapatkan nilai $\mathrm{p}=0,494 \quad(\mathrm{p}>0,05)$ sehingga keputusan uji $\mathrm{HO}$ diterima. Keputusan uji H0 diterima maka disimpulkan bahwa tidak ada hubungan antara asupan kalium dengan dehidrasi pada remaja di SMK Muhammadiyah 04 Boyolali.

Tidak adanya hubungan antara asupan kalium dengan dehidrasi dalam penelitian ini kemungkinan dikarenakan adanya faktor-faktor selain asupan kalium yang berpengaruh besar terhadap kejadian dehidrasi. Secara empiris dalam penelitian ini asupan kalium tidak berhubungan dengan terjadinya dehidrasi namun secara teori ada hubungan antara asupan kalium dengan dehidrasi. Kartasapoetra (2005) mengatakan bahwa fungsi kalium sendiri di dalam tubuh antara lain merupakan unsur organik yang penting dalam cairan intraselular, penting dalam transmisi impuls-impuls syaraf, penting untuk kontraksi otot.

Apabila terjadi defisiensi kalium bukan terjadi karena kurangnya asupan kalium yang melalui makanan namun karena ekskresi yang berlebihan melalui ginjal, muntah terus menerus, dehidrasi dan diare juga dapat menyebabkan defisiensi kalium. Kekurangan kalium atau hipokalemia dapat menyebabkan otot menjadi lemah dan apabila tidak diatasi dapat menyebabkan kelumpuhan (Kartasapoetra, 2005).

\subsection{Hubungan Asupan Natrium dengan Dehi- drasi}

Tabel 11. Analisis asupan natrium berdasarkan dehidrasi

\begin{tabular}{lccccc}
\hline Variabel & Mean & SD & Min & Max & P \\
\hline Asupan & 991,49 & 990,89 & 50,0 & 6631,6 & $0,331^{*}$ \\
Natrium & 5,59 & 1,37 & 3,00 & 8,00 & \\
Dehidrasi & 5,59 & & & & \\
* Rank Spearman & & & &
\end{tabular}

Berdasarkan Tabel 11. menunjukkan bahwa rata-rata asupan natrium adalah 991,49 $\mathrm{mg}$ yang menunjukkan dalam kategori kurang, sedangkan rata-rata dehidrasi 5,59 hal ini menunjukkan dalam kategori dehidrasi ringan. Hasil uji statistik dengan menggunakan metode Rank Spearman didapatkan nilai $\mathrm{p}=0,331 \quad(\mathrm{p}>0,05) \quad$ sehingga keputusan uji H0 diterima. Keputusan uji H0 diterima maka disimpulkan bahwa tidak ada hubungan antara asupan natrium dengan 
dehidrasi pada remaja di SMK Muhammadiyah 04 Boyolali.

Tidak adanya hubungan antara asupan natrium terhadap dehidrasi kemungkinan dikarenakan adanya faktor-faktor lain yang mempengaruhi seperti umur, jenis kelamin, suhu lingkungan, aktivitas fisik. Secara empiris dalam penelitian ini asupan natrium tidak berhubungan dengan terjadinya dehidrasi namun secara teori ada hubungan antara asupan natrium dengan dehidrasi. Fungsi natrium sendiri yaitu menjaga keseimbangan cairan, sebagian besar mengatur tekanan osmosis dan menjaga cairan tidak keluar dari darah dan masuk kedalam sel-sel. Di dalam sel, tekanan osmosis diatur oleh kalium guna menjaga cairan agar tidak keluar dari sel. Secara normal tubuh dapat menjaga keseimbangan antara natrium di luar sel dan kalium di dalam sel (Palmer, 2007).

Bila seseorang mengkonsumsi terlalu banyak garam, kadar natrium darah akan meningkat akan menimbulkan rasa haus, penurunan produksi kencing untuk mengurangi seminimal mungkin cairan yang keluar dan air seni akan tampak lebih pekat dan berwarna gelap (Almatsier, 2001). Asupan cairan tidak dapat mengimbangi pengeluaran cairan, dehidrasi akan lebih berat. Bila dehidrasi berlangsung terus menerus jaringan tubuh akan mulai mengering, sel-sel akan mulai mengerut dan mengalami gangguan fungsi.

\section{SIMPULAN DAN SARAN}

\subsection{Simpulan}

a. Sebagian besar remaja di SMK Muhammadiyah 04 Boyolali memiliki asupan kurang $96,9 \%$.

b. Sebagian besar remaja di SMK Muhammadiyah 04 Boyolali memiliki asupan kurang $79,7 \%$.

c. Remaja di SMK Muhammadiyah 04 Boyolali memiliki hidrasi baik $4,7 \%$, dehidrasi ringan $45,3 \%$, dan dehidrasi berat $50,0 \%$.

d. Tidak ada hubungan asupan kalium dengan kejadian dehidrasi pada remaja di SMK Muhammadiyah 04 Boyolali dengan p-value 0,494 .

e. Tidak ada hubungan asupan natrium dengan kejadian dehidrasi pada remaja di SMK Muhammadiyah 04 Boyolali p-value 0,331.

\subsection{Saran}

a. Bagi remaja SMK Muhammadiyah 04 Boyolali

1) Perlu dilakukan pengecekan rutin dehidrasi dengan pemeriksaan urin sendiri (PURI).

2) Remaja disarankan untuk meningkatkan pengetahuan tentang pencegahan dan dampak kekurangan cairan pada tubuh dan siswa di sarankan jangan menunggu haus terlebih dahulu baru minum agar terhindar dari risiko dehidrasi.

b. Bagi peneliti lain

1) Perlu penelitian lebih lanjut mengenai gangguan keseimbagan elektrolit

2) Perlu penambahan bahan makanan lebih lengkap pada form food frequency (FFQ) semi kuantitatif yang mengandung tinggi kalium dan tinggi natrium

3) Peneliti lain yang akan menggunakan food model diharapkan dapat mengikuti responden atau meminta responden membawa peralatan yang biasa digunakan di rumah untuk melihat ukuran rumah tanggga (URT) agar persepsi yang digunakan sama.

\section{REFERENSI}

Almatsier, Sunita. 2005. Prinsip Dasar Ilmu Gizi. Jakarta: Penerbit PT Gramedia Pustaka Utama.

Almatsier, Sunita. 2006. Penuntun Diet Edisi Baru, Instalasi Gizi Perjan RSCM dan Asosiasi Dietisien Indonesi. Penerbit PT Gramedia Pustaka Utama.

Almatsier, Sunita. 2009. Prinsip Dasar Ilmu Gizi. Jakarta: Penerbit PT Gramedia Pustaka Utama.

Andayani, Tri Murti, 2013. Farmako ekonomi Prinsip dan Metodologi. Yogyakarta: Bursa Ilmu.

Arlita, T. 2014. Hubungan Asupan Natrium, Kalium, magnesium dan Status Gizi dengan Tekanan darah Pada Lansia Di kelurahan Makam Haji Kecamatan Kartasura. Skripsi Thesis, Universitas Muhammadiyah Surakarta. 
Asian Food Information Centre. 2000. Fluid, the Forgotten Factor. http//www. AFIC.org. Diunduh pada tanggal 12 Juli 2016 pukul 19.23 WIB.

Darwis D, Moenajat Y, Nur B.M, Madjid A.S Siregar P, Aniwidyaningsih W, dkk. 2008. Fisiologi Keseimbangan Air dan Elektrolit dalam Gangguan Keseimbangan AirElektrolit dan Asam-Basa, Fisiologi, Patofisiologi, Diagnosis dan Tatalaksana, ed. ke-2, FK-UI.Jakarta: hh. 29-114.

Dila.Y.P.2014.Faktor-faktor yang berhungan dengan perilaku makan pada remaja putri di SMA Negeri 10 PADANG. Fakultas Keperawatan Universitas Andalas

Dwi, B. 2007. Asupan Gizi dan Status Gizi Sebagai Faktor Risiko Hipertensi Pada Lansia di Puskesmas Bengkulu. The Indonesian Journal of Clinical Nutrition. Vol.4 No 1.

Hardinsyah, Sriardiningsih, Razaktaha, Briawan D, Effendi YH, Aries M, Lestari KS, Nindya TS, Hidri N, dan Fatimah S. 2010. Kebiasaan Minum dan Status Hidrasi pada Remaja dan Dewasa di Dua Wilayah Ekologi Berbeda. Tim THIRST (The Indonesian Regional Hydration Study). FEMA IPB. FKM UNAIR dan FKM UNHAS.

Irawan, M.A., 2007. Glukosa dan Metabolisme Energi. Sport Science Brief. 1(6): 12-5.

Kartasapoetra, G.2005. Ilmu Gizi.Jakarta: PT.Rineka Cipta
Listiyaningsih dkk. 2014. Asupan Sumber Natrium, Rasio Kalium Natrium, Aktivitas Fisik, Dan Tekanan Darah Pasien Hipertensi. Yogyakarta

Narendra, M.S, dkk. 2008. Buku Ajar Tumbuh Kembang Anak dan Remaja. Jakarta.

Nasution, AH., dan Darwin K. 1998. Pengetahuan Gizi Muthakir Mineral. Jakarta: PT. Gramedia.

Nirmala. 2010. Nutrition and Food. Jakarta: PT Kompas Media Nusantara.

Palmer, A. dan Williams, B. 2007. Simple Guides Tekanan Darah Tinggi. Jakarta: EGC.

Proverawati, A dan Wati, E K. 2011. Ilmu Gizi untuk Perawat dan Gizi Kesehatan. Yogyakarta: Yulia Medika.

Ridwan dan Akdon. 2010. Rumus dan Data dalam Analisis Statistika. Bandung: Alfabeta.

Scott M.G., LeGrys, V.A. and Klutts J. 2006. Electrochemistry and Chemical Sensors and Electrolytes and Blood Gases In: Tietz Text Book of Clinical Chemistry and Molecular Diagnostics, 4th Ed. Vol.1, Elsevier Saunders Inc., Philadelphia, pp. 93-1014.

Yaswir, R., Ira Ferawati. 2012. Fisiologi dan Gangguan Keseimbangan Natrium, Kalium dan Klorida serta Pemeriksaan Laboratorium. Jurnal Kesehatan Andalas 2012;1(2) FK-Unand. 